\begin{tabular}{l|l|l|l|l}
\hline Volume 2 & Issue 2 & August (2021) & DOI: 10.47540/ijsei.v2i2.264 & Page: $176-187$ \\
\hline
\end{tabular}

\title{
Effect of Mycorrhizal Inoculation on Growth and Nutrients Uptake of Maize Grown on Crude Oil Contaminated Soil
}

\author{
Kingsley Uzoma ${ }^{1}$, Michael E. Nkereuwem², Uzaifa K. Adamu ${ }^{3}$, Adeniyi O. Adeleye ${ }^{4}$, Abe \\ Mololuwa $^{5}$ \\ ${ }^{1}$ Michael Okpara University of Agriculture, Umudike, Abia State, Nigeria \\ ${ }^{2,3}$ Department of Soil Science, Federal University Dutse, Dutse, Jigawa State, Nigeria \\ ${ }^{4}$ Department of Environmental Sciences, Federal University Dutse, Dutse, Jigawa State, Nigeria \\ ${ }^{5}$ Federal University of Agriculture, Abeokuta, Ogun State, Nigeria
}

Corresponding Author: Michael E. Nkereuwem; Email: michael.n@fud.edu.ng

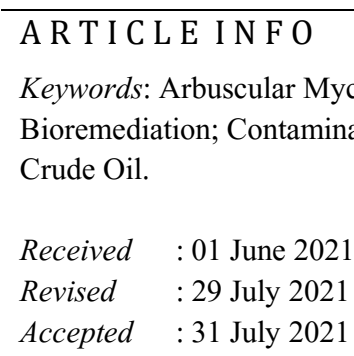

A B S T R A C T

This study was carried out to evaluate the effect of mycorrhizal inoculation on the growth and nutrients uptake of maize planted in crude oil-contaminated soil. About $10 \mathrm{~kg}$ sterilized topsoil was contaminated with Bonny light crude oil (BLCO) at different concentrations: $0,200,300$, and $500 \mathrm{ml} /$ pot. Maize was sown at three seeds per pot and later thinned to two stands per pot after two weeks. Inoculation in treatments containing AM consisted of $20 \mathrm{~g}$ of Glomus clarum. Data on residual TPH content of the soil, plant height, number of leaves, fresh and dry weights, and nutrients uptake were collected at 4, 8, and 12 weeks after sowing (WAS). The $2 \times 4$ factorial experiment was laid in a completely randomized design and replicated 3 times. The results obtained indicated that AM inoculated maize had higher and significantly $(\mathrm{p}<0.05)$ nitrogen, phosphorus, potassium, calcium, plant height, number of leaves, fresh and dry weights. Significantly $(\mathrm{p}<0.05)$ lower residual TPH content was recorded with treatments inoculated with AM fungi compared to nonAM fungi inoculated treatments. AM colonization resulted in enhanced nutrients uptake thus, improving the physiological parameters of the test crop.

\section{INTRODUCTION}

Crude oil spillage is one of the main sources of environmental pollution, especially in production areas. The environmental impact of crude oil pollution is severe on soils and vegetation on which rural livelihoods depend. Soils contaminated with crude oil are of environmental concern because such soils are not suitable for agricultural and recreational activities and are potential sources of surface and groundwater contamination (Schwab et al., 1999; Adipah, 2019). Petroleum can suppress plant growth through a variety of mechanisms, including the displacement of air from soil pore spaces, an increase in oxygen demand caused by the activities of oil-decomposing microorganisms, and the creation of a hydrophobic environment, which inhibits water absorption by plant roots (Schnoor, 1997; Oyedejii et al, 2012; Adipah, 2019). Soil pollution destroys soil fertility, hamper proper plant growth, and destroys beneficial soil microbes (Uquetan et al., 2017). The increasing dependence on petroleum hydrocarbons as a major energy source for both homes and industries has led to the pollution of agricultural lands due to oil spillage during exploration and processing operations.

Soil washing and flushing, solidification, stabilization, vapor extraction, etc. are some of the several physicochemical methods adopted for the rehabilitation of petroleum hydrocarbons polluted soils (Dadrasnia et al., 2015; Frick et al.,1999). Nevertheless, these methods are expensive, ineffective, and require continuous monitoring and control for optimum performance (Gong, 2012; Dadrasnia et al., 2015; Frick et al., 1999). A better strategy to overcome these drawbacks is bioremediation techniques. 
Bioremediation involves the use of microorganisms (bacteria, fungi, etc.) and/or plants in the rehabilitation of organic compounds impacted soils. These techniques are economical, eco-friendly, and have shown encouraging and effective results in the treatment of soils contaminated with organic pollutants; notably petroleum hydrocarbons (Soleimani et al., Graj et al., 2013; Nkereuwem et al., 2020a). Mycorrhizas are symbiotic relationships between plant roots and a variety of filamentous fungi that live in the soil. Arbuscular mycorrhiza (AM) fungi exhibit some exceptional traits such as vigorous growth, extensive hyphal network, adaptability to fluctuating $\mathrm{pH}$ and temperatures, high surface area to volume ratio, translocation of nutrients and water, production of many bioactive compounds and extracellular enzymes, and the unique capability to co-metabolize many environmental chemicals (Khan et al., 2019; Singh et al., 2015; Kapahi and Sachdeva, 2015; Harms et al., 2011). These characteristics make AM fungi more desirable in the bioremediation of contaminated soils compared with other microorganisms (Bharath et al., 2019; de Lima Souza et al., 2016). Additionally, collaborative effects of AM fungi with some microorganisms in the phytoremediation process have been reported (Alcorn et al., 2008; Liu and Dalpe, 2009; Teng et al., 2010).

Therefore, the study seeks to: 1) determine the effect of AM fungi on growth and nutrient uptake of maize (Zea mays L.) planted in crude oil contaminated soil and 2) the effectiveness of AM fungi in remediation of crude oil contaminated soil as well as enhancing the survival of the test crop in crude oil-contaminated soil.

\section{Materials AND MeTHOdS}

\section{Experimental site and planting materials}

The study was carried out at the Department of Botany Teaching and Research Farm, University of Uyo, Uyo, Akwa Ibom State. The arbuscular mycorrhiza (AM) fungi used for the study was sourced from the Soil Microbiology Laboratory, Department of Soil Resources Management, University of Ibadan, Ibadan, Oyo State. Bonny Light Crude oil was obtained from Nigerian National Petroleum Corporation (NNPC), Port Harcourt refinery, Rivers State. Maize seed (Oba
98) was sourced from National Root Crops Research Institute (NRCRI), Umudike, Abia State.

\section{Soil preparation}

Soil samples at depth $0-15 \mathrm{~cm}$ were collected, air-dried, sieved through a $2 \mathrm{~mm}$ sieve, sterilized, and then filled into $10 \mathrm{~kg}$ capacity pots.

\section{Planting and management}

The crude oil at 200,300, and $500 \mathrm{mls} /$ pot were mixed thoroughly with the soil and allowed to stand for two weeks. Maize was sown at three seeds per pot and later thinned to two stands per pot after two weeks. Inoculation in treatments containing Glomus clarum consisted of $20 \mathrm{~g}$ of root-soil-fungal mixture blended into the central third of the soil at sowing (Carling et al., 1978).

\section{Data collection}

Plant height and the number of leaves were determined at 4, 8, and 12 weeks after sowing (WAS). The plant height $(\mathrm{cm})$ was measured with the aid of a meter rule while the number of leaves was visually counted. Dry weight (g) was evaluated by oven drying the fresh biomass of the maize plant at $65^{\circ} \mathrm{C}$ to a constant weight. The total petroleum hydrocarbon (TPH) content of the soil was determined at 4, 8, and 12 WAS using the Soxhlet extraction method (USEPA, 2017).

\section{Experimental design}

The experimental design was completely randomized design replicated three times. It was a factorial experiment with two factors; mycorrhizal inoculation at two levels (with and without) and crude oil contamination at four levels $(0,200,300$, and $500 \mathrm{mls} / \mathrm{pot}$ ) making a total of 8 treatment combinations. The treatments were:

\section{Factors:}

(a) Mycorrhizal inoculum (20 g)

i. Glomus clarum inoculation

ii. Without Glomus clarum inoculation

(b) Crude oil (Bonny Light) contaminant
i. No crude oil
ii. $20 \mathrm{ml} / \mathrm{kg}$ soil; $200 \mathrm{mls} /$ pot
iii. $30 \mathrm{ml} / \mathrm{kg}$ soil; $300 \mathrm{mls} /$ pot
iv. $50 \mathrm{ml} / \mathrm{kg}$ soil; $500 \mathrm{mls} /$ pot

\section{Determination of the physicochemical properties of the soil sample}

The particle size of the soil was determined by the hydrometer method of Bouyoucos (1951), while the soil $\mathrm{pH}$ was determined according to Udoh and Ogunwale (1986). The organic carbon was estimated by the modified procedure of Walkley- 
Black (Nelson and Sommers, 1996). The total nitrogen and available phosphorus content of the soil were determined by the micro Kjeldahl digestion and distillation method as described by Udoh and Ogunwale (1986) and Bray P1 method (Bray and Kurtz, 1945). The exchangeable bases ( $\mathrm{K}, \mathrm{Ca}, \mathrm{Na}$ and $\mathrm{Mg}$ ) were estimated according to Jackson (1958). Ca and Mg were read off using atomic absorption spectrophotometer (AAS) while $\mathrm{K}$ and $\mathrm{Na}$ were read off using a flame photometer. Similarly, effective cation exchange capacity was determined by the summation method of Juo et al. (1976), while the exchangeable acidity was estimated by the method of Mclean (1982).

\section{Plant analysis}

Total $\mathrm{N}$ was determined from the digest by steam distillation with excess $\mathrm{NaOH}$ and boric acid indicator and then titrated with $0.01 \mathrm{NHCl}$ solution. $\mathrm{P}$ concentration was determined by the vanadomolyb date yellow colorimetric method using a spectrophotometer (Olsen et al., 1954). The $\mathrm{K}$ was determined with the flame photometer (Jenway model) (Olsen et al., 1954) while $\mathrm{Ca}$ and $\mathrm{Mg}$ were determined with Atomic absorption spectrophotometer (AAS) (Buck Scientific Atomic Spectrophotometer, Model 210/211 VGP). Nutrient accumulated in the plant was calculated thus:
Nutrient uptake $=\%$ nutrient content $\times$ dry weight of above-ground shoot biomass

\section{The total petroleum hydrocarbon (TPH)}

The soxhlet extraction method was used to estimate the TPH content. Analytical determinations of the hydrocarbons in the soil extracts were performed by an Infrared spectrophotometer (IR). Quantification of the TPH content was carried out using the procedure described by the USEPA SW846 series method 3540 (USEPA, 2017). After collection of the extract, it was passed through sodium sulfate and silica gel to remove water and polar constituents. An aliquot of the soil extract was then placed in the infrared spectrophotometry (IR) analyzer. The TPH value was determined by comparing it to a three-point calibration curve constructed from dilutions of a stock solution of a 2:3:3 volume ratio of chloro-benzene, isooctane, and n-hexadecane made up in perchloroethylene (PCE), according to USEPA (2017).

\section{Statistical analysis}

All data collected were subjected to analysis of variance (ANOVA) by Proc. GLM of GenStat version 17 and significant means were separated using appropriate post-hoc tools.

\section{RESULTS AND DisCUSSION}

Table 1. Physical and chemical properties of the soil sample used in the different experimental assays

\begin{tabular}{|c|c|}
\hline Soil properties & Value \\
\hline $\mathrm{pH}\left(\mathrm{H}_{2} \mathrm{O}\right)$ & 4.9 \\
\hline $\mathrm{C}(\mathrm{g} / \mathrm{kg})$ & 12.4 \\
\hline $\mathrm{N}(\mathrm{g} / \mathrm{kg})$ & 1.0 \\
\hline Av. P $(\mathrm{mg} / \mathrm{kg})$ & 28.70 \\
\hline Moisture content $(\%)$ & 7.8 \\
\hline Exchangeable cations $(\mathrm{cmol} / \mathrm{kg})$ & 6.0 \\
\hline $\mathrm{Ca}$ & 1.2 \\
\hline $\mathrm{Mg}$ & 0.12 \\
\hline $\mathrm{K}$ & 0.08 \\
\hline $\mathrm{Na}$ & 0.16 \\
\hline $\mathrm{Al}$ & 0.82 \\
\hline $\mathrm{H}^{+}$ & 8.4 \\
\hline ECEC $(\mathrm{cmol} / \mathrm{kg})$ & 840 \\
\hline Particle size $(\mathrm{g} / \mathrm{kg})$ & 110 \\
\hline Sand & 50 \\
\hline Silt & Sandy \\
\hline Clay & \\
\hline Textural class & \\
\hline & \\
\hline & \\
\hline
\end{tabular}


Table 1 above shows the physicochemical properties of the soil used for the experiment with a $\mathrm{pH}$ of 4.9 while the values of the major nutrient elements are as follows: Total N $1.0 \mathrm{~g} / \mathrm{kg}$, Available
P $28.70 \mathrm{mg} / \mathrm{kg}$, exchangeable $\mathrm{K} 0.12 \mathrm{cmol} / \mathrm{kg}$, Ca $6.0 \mathrm{cmol} / \mathrm{kg}$ and $\mathrm{Mg} 1.2 \mathrm{cmol} / \mathrm{kg}$. The textural class of the soil is sand.

Table 2. Effect of Mycorrhizal Inoculation and Crude Oil on Plant Height and Number of Leaves of maize at different Weeks After Sowing (WAS).

\begin{tabular}{|c|c|c|c|c|c|c|}
\hline \multirow{2}{*}{ Treatments } & \multicolumn{3}{|c|}{ Plant height $(\mathrm{cm})$} & \multicolumn{3}{|c|}{ Number of leaves } \\
\hline & 4WAS & 8WAS & 12WAS & 4WAS & $8 \mathrm{WAS}$ & $12 \mathrm{WAS}$ \\
\hline \multicolumn{7}{|c|}{ Mycorrhizal inoculation } \\
\hline $\mathrm{M}^{+}$ & 47.14 & 76.07 & 103.91 & 10.28 & 11.69 & 13.47 \\
\hline $\mathrm{M}^{-}$ & 46.02 & 74.35 & 102.87 & 8.75 & 10.11 & 11.64 \\
\hline LSD (0.05) & NS & NS & NS & 0.36 & 0.43 & 0.45 \\
\hline \multicolumn{7}{|c|}{ Crude oil (ml/pot) } \\
\hline $\mathrm{C}_{0}$ & 69.69 & 128.27 & 160.84 & 11.00 & 12.72 & 14.67 \\
\hline $\mathrm{C}_{200}$ & 39.43 & 58.36 & 88.54 & 9.72 & 10.83 & 12.22 \\
\hline $\mathrm{C}_{300}$ & 39.26 & 57.52 & 87.29 & 8.83 & 10.17 & 12.00 \\
\hline $\mathrm{C}_{500}$ & 37.93 & 55.68 & 75.91 & 8.50 & 9.89 & 11.33 \\
\hline LSD (0.05) & 2.01 & 2.88 & 2.38 & 0.50 & 0.61 & 0.64 \\
\hline
\end{tabular}

$\mathrm{M}+=$ with Glomus clarum; $\mathrm{M}-=$ without Glomus clarum; $\mathrm{C} 0=0 \mathrm{ml} ; \mathrm{C} 1=200 \mathrm{mls} ; \mathrm{C} 2=300 \mathrm{mls} ; \mathrm{C} 3=$ $500 \mathrm{mls} ; \mathrm{LSD}=$ Least significant difference, $\mathrm{NS}=$ Not significant.

Mycorrhizal inoculation resulted in higher plant height of maize at 4,8 , and 12 WAS however, this was not significantly higher compared with non-mycorrhizal inoculation (Table 2). Significantly higher $(p<0.05)$ number of leaves of maize plant were obtained with mycorrhizal inoculation compared with non-mycorrhizal inoculation in all the weeks evaluated (Table 2)

Within all levels of crude oil application (except control), there was no significant difference in the heights of maize at 4 and 8 WAS, however at $12 \mathrm{WAS}$, maize plant height under $500 \mathrm{ml} /$ pot crude oil was significantly lower $(76.91 \mathrm{~cm})$ compared to those of 300 and $200 \mathrm{mls} /$ pot crude oil $(87.29$ and $88.54 \mathrm{~cm}$ ) (Table 2). Furthermore, 200 and 300 $\mathrm{mls} /$ pot crude oil applications were not significantly different.

The number of leaves of the maize plant was significantly higher $(10.28,11.69$, and 13.47$)$ with mycorrhizal inoculation compared to nonmycorrhizal inoculation $(8.75,10.11$, and 11.64$)$ in all the weeks' evaluated (Table 2).

Crude oil application at $0 \mathrm{ml} /$ pot resulted in a significantly higher number of leaves of maize plant at 4,8 , and 12 WAS compared to other application levels (Table 2). Furthermore, crude oil application at $200 \mathrm{mls} /$ pot at 4 and $8 \mathrm{WAS}$ also resulted in a significantly higher (9.72 and 10.83) number of leaves of maize plant compared to those of 300 and $500 \mathrm{mls} /$ pot (8.83 and 10.17 and 8.50 and 9.89) while 300 and $500 \mathrm{mls} /$ pot were not significantly different. At $12 \mathrm{WAS}, 200$ and $300 \mathrm{mls} /$ pot crude oil were not significantly different (12.22 and 12.00) but had significantly higher values compared to that of $500 \mathrm{mls} /$ pot crude oil (11.33) while 300 $\mathrm{mls} /$ pot crude oil had a significantly higher number of leaves of maize plant compared to that of 500 $\mathrm{mls} /$ pot crude oil. 
Table 3. Effect of mycorrhizal inoculation and crude oil on the fresh and dry weight of maize at different weeks after sowing (WAS)

\begin{tabular}{|c|c|c|c|c|c|c|}
\hline \multirow{2}{*}{ Treatments } & \multicolumn{3}{|c|}{ Fresh weight (g) } & \multicolumn{3}{|c|}{ Dry weight } \\
\hline & 4WAS & $8 \mathrm{WAS}$ & $12 \mathrm{WAS}$ & 4WAS & $8 \mathrm{WAS}$ & $12 \mathrm{WAS}$ \\
\hline \multicolumn{7}{|c|}{ Mycorrhizal inoculation } \\
\hline $\mathrm{M}^{+}$ & 70.30 & 101.77 & 132.50 & 38.06 & 50.44 & 66.35 \\
\hline $\mathrm{M}^{-}$ & 73.76 & 96.50 & 127.81 & 34.00 & 47.67 & 64.82 \\
\hline LSD (0.05) & 0.96 & 1.07 & 1.38 & 1.05 & 1.13 & 0.98 \\
\hline \multicolumn{7}{|c|}{ Crude oil (ml/pot) } \\
\hline $\mathrm{C}_{0}$ & 130.49 & 172.58 & 229.76 & 63.43 & 82.52 & 112.46 \\
\hline $\mathrm{C}_{200}$ & 54.83 & 84.70 & 117.26 & 27.82 & 43.83 & 61.21 \\
\hline $\mathrm{C}_{300}$ & 51.73 & 71.43 & 95.12 & 27.00 & 36.34 & 48.94 \\
\hline $\mathrm{C}_{500}$ & 51.06 & 67.85 & 78.49 & 25.88 & 33.52 & 39.72 \\
\hline LSD (0.05) & 1.36 & 1.51 & 1.81 & 1.42 & 1.59 & 1.38 \\
\hline
\end{tabular}

$\mathrm{M}+=$ with Glomus clarum; $\mathrm{M}-=$ without Glomus clarum; $\mathrm{C} 0=0 \mathrm{ml} ; \mathrm{C} 1=200 \mathrm{mls} ; \mathrm{C} 2=300 \mathrm{mls} ; \mathrm{C} 3=$ $500 \mathrm{mls} ; \mathrm{LSD}=$ Least significant difference, $\mathrm{NS}=$ Not significant

Mycorrhiza inoculated plants at 8 and 12 WAS had significantly higher fresh weight compared to non-mycorrhiza inoculated plants (Table 3) whereas at 4 WAS, non-mycorrhiza inoculated plants had significantly higher (73.76) fresh weight compared to mycorrhiza inoculated plants (70.30).

At 8 and 12 WAS, mycorrhizal inoculated plants had significantly higher dry weights $(50.44$ and $66.35 \mathrm{~g})$ compared to non-mycorrhizal inoculated plants (Table 3) although at 4 WAS, non-mycorrhiza inoculated plant was significantly higher compared to mycorrhiza inoculated plant.

At all the weeks evaluated, significantly higher dry weights $(63.43,82.52$, and $112.46 \mathrm{~g})$ were

Table 4. Interactions of Mycorrhiza Inoculation with Crude Oil on Plant Height and Number of Leaves of maize at different Weeks After Sowing (WAS)

\begin{tabular}{|c|c|c|c|c|c|c|c|}
\hline \multirow{2}{*}{$\begin{array}{l}\text { Mycorrhizal } \\
\text { Inoculation }\end{array}$} & \multirow{2}{*}{$\begin{array}{c}\text { Crude Oil } \\
\text { (ml/pot) }\end{array}$} & \multicolumn{3}{|c|}{ Plant height $(\mathrm{cm})$} & \multicolumn{3}{|c|}{ Number of leaves } \\
\hline & & 4WAS & $8 \mathrm{WAS}$ & $12 \mathrm{WAS}$ & $4 \mathrm{WAS}$ & $8 \mathrm{WAS}$ & $12 \mathrm{WAS}$ \\
\hline $\mathrm{M}^{+}$ & $\overline{\mathrm{C}_{0}}$ & $69.93 a$ & $130.06 a$ & $160.89 a$ & $11.89 \mathrm{a}$ & $13.56 \mathrm{a}$ & $15.67 \mathrm{a}$ \\
\hline $\mathrm{M}^{+}$ & $\mathrm{C}_{200}$ & $39.98 b$ & $58.53 b$ & $89.09 \mathrm{~b}$ & $10.33 b$ & $11.56 \mathrm{bc}$ & $13.11 b c$ \\
\hline $\mathrm{M}^{+}$ & $\mathrm{C}_{300}$ & $39.84 b$ & $57.53 b$ & $88.01 \mathrm{~b}$ & $9.56 \mathrm{~cd}$ & $10.89 \mathrm{~cd}$ & $12.89 \mathrm{bc}$ \\
\hline $\mathrm{M}^{+}$ & $\mathrm{C}_{500}$ & $38.80 \mathrm{~b}$ & $58.02 b$ & $77.70 \mathrm{c}$ & $9.33 d$ & $10.78 \mathrm{~cd}$ & $12.22 \mathrm{~cd}$ \\
\hline $\mathrm{M}^{-}$ & $\mathrm{C}_{0}$ & $69.44 a$ & $126.48 \mathrm{a}$ & $160.79 a$ & $10.11 b c$ & $11.89 \mathrm{~b}$ & $13.67 \mathrm{~b}$ \\
\hline $\mathrm{M}^{-}$ & $\mathrm{C}_{200}$ & $39.02 b$ & $58.06 \mathrm{~b}$ & $88.02 \mathrm{~b}$ & $9.11 d$ & $10.11 \mathrm{de}$ & $1.33 \mathrm{de}$ \\
\hline $\mathrm{M}^{-}$ & $\mathrm{C}_{300}$ & $38.54 b$ & $57.03 b$ & $86.57 b$ & $8.11 \mathrm{e}$ & 9.44ef & $11.11 \mathrm{e}$ \\
\hline $\mathrm{M}^{-}$ & $\mathrm{C}_{500}$ & $37.05 \mathrm{~b}$ & $55.82 \mathrm{~b}$ & $76.11 \mathrm{c}$ & $7.67 \mathrm{e}$ & $9.00 \mathrm{f}$ & $10.44 \mathrm{e}$ \\
\hline
\end{tabular}

Means with the same letter(s) in the same column are not significantly different from each other at $\mathrm{p}<0.05$ using Duncan's multiple range test, $\mathrm{M}+=$ with Glomus clarum; $\mathrm{M}-=$ without Glomus clarum; $\mathrm{C} 0=0 \mathrm{ml}$; $\mathrm{C} 1=200 \mathrm{mls} ; \mathrm{C} 2=300 \mathrm{mls} ; \mathrm{C} 3=500 \mathrm{mls}$

Within all levels of interaction between mycorrhizal inoculation and crude oil (except with and without mycorrhizal inoculations with $0 \mathrm{ml} /$ pot obtained with the application of $0 \mathrm{ml} /$ pot crude oil compared to other levels of application (Table 3) while $500 \mathrm{mls} /$ pot crude oil at 4WAS had significantly lower dry weight (25.88) compared to those of 300 and $200 \mathrm{mls} /$ pot crude oil application. Crude oil applications at 200 and $300 \mathrm{mls} /$ pot were not significantly different at 4 WAS. At 8 and 12 WAS, significantly higher dry weights were obtained with crude oil application at $200 \mathrm{mls} / \mathrm{pot}$ compared to those of 300 and $500 \mathrm{mls} /$ pot crude oil applications while crude oil application at 500 $\mathrm{mls} /$ pot was also significantly lower compared to that of $300 \mathrm{mls} /$ pot. 
application of $500 \mathrm{mls} /$ pot crude oil with nonmycorrhizal inoculation resulted in significantly lower values $(76.11 \mathrm{~cm})$ compared to those of with and without mycorrhizal inoculations with crude oil applications at 200 and $300 \mathrm{mls} /$ pot respectively (Table 4). Furthermore, with and without mycorrhizal inoculations with 200 and $300 \mathrm{mls} /$ pot crude oil were not significantly different.

Combined application of mycorrhiza with 0 $\mathrm{ml} /$ pot crude oil resulted in a significantly higher
(11.89, 13.56, and 15.67) number of leaves at 4, 8, and 12 WAS compared to other treatments (Table 4) while $500 \mathrm{mls} /$ pot crude oil with nonmycorrhizal inoculation had significantly lower (7.67, 9.00 and 10.44) maize plant leaves compared to that of mycorrhizal inoculation with $500 \mathrm{mls} /$ pot crude oil. At 8 and 12 WAS, the number of leaves of maize plants inoculated with mycorrhiza under 200 and $300 \mathrm{mls} /$ pot crude oil were not significantly different.

Table 5. Interactions of Mycorrhiza Inoculation with Crude Oil on Fresh and Dry Weights of maize at different Weeks After Sowing (WAS)

\begin{tabular}{|l|l|l|l|l|l|l|l|}
\hline \multirow{2}{*}{$\begin{array}{c}\text { Mycorrhizal } \\
\text { inoculation }\end{array}$} & $\begin{array}{c}\text { Crude oil } \\
(\mathrm{ml} / \text { pot })\end{array}$ & \multicolumn{4}{|c|}{ Fresh weight (g) } & \multicolumn{4}{c|}{ Dry weight (g) } \\
\hline M+ & $\mathrm{C}_{0}$ & $131.10 \mathrm{a}$ & $173.32 \mathrm{a}$ & $230.95 \mathrm{a}$ & $66.90 \mathrm{a}$ & $83.69 \mathrm{a}$ & $111.19 \mathrm{~b}$ \\
\hline $\mathrm{M}+$ & $\mathrm{C}_{200}$ & $56.33 \mathrm{~b}$ & $86.09 \mathrm{~b}$ & $119.13 \mathrm{~b}$ & $29.38 \mathrm{c}$ & $44.84 \mathrm{c}$ & $62.21 \mathrm{c}$ \\
\hline $\mathrm{M}+$ & $\mathrm{C}_{300}$ & $54.51 \mathrm{bc}$ & $76.00 \mathrm{c}$ & $97.55 \mathrm{~d}$ & $28.31 \mathrm{~cd}$ & $37.45 \mathrm{~d}$ & $49.76 \mathrm{e}$ \\
\hline $\mathrm{M}+$ & $\mathrm{C}_{500}$ & $53.11 \mathrm{c}$ & $71.68 \mathrm{~d}$ & $82.40 \mathrm{f}$ & $27.66 \mathrm{cde}$ & $35.76 \mathrm{~d}$ & $42.23 \mathrm{f}$ \\
\hline M- & $\mathrm{C}_{0}$ & $129.89 \mathrm{a}$ & $171.83 \mathrm{a}$ & $228.57 \mathrm{a}$ & $59.96 \mathrm{~b}$ & $81.35 \mathrm{~b}$ & $113.73 \mathrm{a}$ \\
\hline M- & $\mathrm{C}_{200}$ & $53.34 \mathrm{c}$ & $83.32 \mathrm{~b}$ & $115.39 \mathrm{c}$ & $26.27 \mathrm{de}$ & $42.82 \mathrm{c}$ & $60.21 \mathrm{~d}$ \\
\hline M- & $\mathrm{C}_{300}$ & $49 \mathrm{~d}$ & $66.85 \mathrm{e}$ & $92.68 \mathrm{e}$ & $25.69 \mathrm{ef}$ & $35.24 \mathrm{~d}$ & $48.12 \mathrm{e}$ \\
\hline M- & $\mathrm{C}_{500}$ & $48.99 \mathrm{~d}$ & $64.01 \mathrm{e}$ & $74.61 \mathrm{~g}$ & $24.10 \mathrm{f}$ & $31.27 \mathrm{e}$ & $37.20 \mathrm{~g}$ \\
\hline
\end{tabular}

Means with the same letter(s) in the same column are not significantly different from each other at $\mathrm{p}<0.05$ using Duncan's multiple range test, $\mathrm{M}+=$ with Glomus clarum; $\mathrm{M}-=$ without Glomus clarum; $\mathrm{C} 0=0 \mathrm{ml}$; $\mathrm{C} 1=200 \mathrm{mls} ; \mathrm{C} 2=300 \mathrm{mls} ; \mathrm{C} 3=500 \mathrm{mls}$

At 4,8 and 12 WAS, significantly higher $(131.10,173.32$, and $230.95 \mathrm{~g})$ fresh biomass of maize was obtained from the interaction of mycorrhiza with $0 \mathrm{ml} /$ pot crude oil compared to other treatments (Table 5) while significantly lower $(48.99,64.01$ and $74.61 \mathrm{~g})$ fresh biomass of maize plant was obtained with the combined application of $500 \mathrm{mls} /$ pot crude oil with non-mycorrhizal inoculation. However, crude oil application at 500 and $300 \mathrm{mls} /$ pot with non-mycorrhizal inoculation was not significantly different except at 12 WAS. In addition, mycorrhizal inoculation with 200 and 300 $\mathrm{mls} /$ pot crude oil and $200 \mathrm{mls} /$ pot crude oil with non-mycorrhizal inoculation were not significantly different.

Mycorrhiza inoculation with $0 \mathrm{ml} /$ pot crude oil resulted in significantly higher (66.90 and $83.69 \mathrm{~g}$ ) dry biomass of maize plant at 4 and 8 WAS compared to other treatments (Table 5), however at 12 WAS, significantly higher (113.73 g) maize dry biomass was obtained from the combined use of 0 $\mathrm{ml} /$ pot crude oil and without mycorrhizal inoculation. Significantly lower $(24.10,31.27$, and $37.20 \mathrm{~g}$ ) maize dry weights were obtained from the application of $500 \mathrm{mls} /$ pot crude oil and without mycorrhizal inoculation compared to that of mycorrhizal inoculated with $500 \mathrm{mls} /$ pot crude oil but at 4 WAS, 500 and $300 \mathrm{mls} /$ pot crude oil and without mycorrhizal inoculation were not significantly different. Furthermore, at 4 WAS, mycorrhizal inoculation with 200, 300, and 500 $\mathrm{mls} /$ pot crude oil was also not significantly different. 
Table 6. Effect of mycorrhizal inoculation and crude oil on nutrients uptake $(\mathrm{mg} / \mathrm{kg})$ in maize

\begin{tabular}{|c|c|c|c|c|c|}
\hline \multicolumn{1}{c}{ Treatments } & $\mathrm{N}$ & $\mathrm{P}$ & $\mathrm{K}$ & $\mathrm{Ca}$ & $\mathrm{Mg}$ \\
\hline $\begin{array}{c}\text { Mycorrhizal } \\
\text { inoculation }\end{array}$ & & & & & \\
\hline $\mathrm{M}^{+}$ & 3.08 & 0.21 & 0.33 & 2.82 & 0.94 \\
\hline $\mathrm{M}$ & 2.79 & 0.16 & 0.16 & 2.19 & 0.95 \\
\hline $\mathrm{LSD}(0.05)$ & 0.10 & 0.003 & 0.10 & 0.22 & $\mathrm{NS}$ \\
\hline $\begin{array}{c}\text { Crude oil } \\
\text { (ml/pot) }\end{array}$ & & & & & \\
\hline $\mathrm{C}_{0}$ & 3.38 & 0.31 & 0.38 & 3.41 & 1.22 \\
\hline $\mathrm{C}_{200}$ & 3.34 & 0.17 & 0.31 & 2.23 & 1.11 \\
\hline $\mathrm{C}_{300}$ & 2.68 & 0.15 & 0.17 & 2.22 & 0.76 \\
\hline $\mathrm{C}_{500}$ & 2.34 & 0.13 & 0.13 & 2.14 & 0.70 \\
\hline LSD $(0.05)$ & 0.15 & 0.004 & 0.14 & 0.31 & 0.05 \\
\hline
\end{tabular}

$\mathrm{M}+=$ with Glomus clarum; $\mathrm{M}-=$ without Glomus clarum; $\mathrm{C} 0=0 \mathrm{ml} ; \mathrm{C} 1=200 \mathrm{mls} ; \mathrm{C} 2=300 \mathrm{mls}$; $\mathrm{C} 3=$ $500 \mathrm{mls} ; \mathrm{LSD}=$ Least significant difference, $\mathrm{NS}=$ Not significant

The nitrogen, phosphorus, potassium, and calcium uptakes $(3.08,0.21,0.33$, and $2.82 \mathrm{mg} / \mathrm{kg})$ by maize plants were significantly enhanced by mycorrhiza inoculation compared to nonmycorrhiza inoculation (Table 6) while there was no significant difference in the magnesium uptake regarding mycorrhiza inoculation.

Regarding nutrients uptake by maize, significantly higher $(3.38,0.31,0.38,3.41$, and 1.22

Table 7. Interaction of mycorrhizal Inoculation with Crude On the nutrient's uptake $(\mathrm{mg} / \mathrm{kg})$ in maize.

\begin{tabular}{c|c|c|c|c|c|c|}
\hline $\begin{array}{c}\text { Mycorrhizal } \\
\text { Inoculation }\end{array}$ & $\begin{array}{c}\text { Crude Oil } \\
(\mathrm{ml} / \mathrm{pot})\end{array}$ & $\mathrm{N}$ uptake & P uptake & K uptake & Ca uptake & Mg uptake \\
\hline $\mathrm{M}^{+}$ & $\mathrm{C}_{0}$ & $3.62 \mathrm{a}$ & $0.34 \mathrm{a}$ & $0.63 \mathrm{a}$ & $3.82 \mathrm{a}$ & $1.23 \mathrm{a}$ \\
\hline $\mathrm{M}^{+}$ & $\mathrm{C}_{200}$ & $3.27 \mathrm{bc}$ & $0.19 \mathrm{c}$ & $0.28 \mathrm{~b}$ & $2.64 \mathrm{bc}$ & $1.13 \mathrm{~b}$ \\
\hline $\mathrm{M}^{+}$ & $\mathrm{C}_{300}$ & $2.90 \mathrm{~d}$ & $0.14 \mathrm{e}$ & $0.14 \mathrm{~b}$ & $2.31 \mathrm{~cd}$ & $0.80 \mathrm{c}$ \\
\hline $\mathrm{M}^{+}$ & $\mathrm{C}_{500}$ & $2.46 \mathrm{e}$ & $0.12 \mathrm{f}$ & $0.11 \mathrm{~b}$ & $1.97 \mathrm{de}$ & $0.65 \mathrm{e}$ \\
\hline $\mathrm{M}^{-}$ & $\mathrm{C}_{0}$ & $3.41 \mathrm{~b}$ & $0.28 \mathrm{~b}$ & $0.34 \mathrm{~b}$ & $3.01 \mathrm{~b}$ & $1.21 \mathrm{a}$ \\
\hline $\mathrm{M}^{-}$ & $\mathrm{C}_{200}$ & $3.13 \mathrm{c}$ & $0.17 \mathrm{~d}$ & $0.19 \mathrm{~b}$ & $2.49 \mathrm{c}$ & $1.08 \mathrm{~b}$ \\
\hline $\mathrm{M}^{-}$ & $\mathrm{C}_{300}$ & $2.53 \mathrm{e}$ & $0.14 \mathrm{e}$ & $0.14 \mathrm{~b}$ & $1.97 \mathrm{de}$ & $0.76 \mathrm{~cd}$ \\
\hline $\mathrm{M}^{-}$ & $\mathrm{C}_{500}$ & $2.14 \mathrm{f}$ & $0.11 \mathrm{~g}$ & $0.12 \mathrm{~b}$ & $1.80 \mathrm{e}$ & $0.72 \mathrm{de}$ \\
\hline
\end{tabular}

Means with the same letter(s) along the column are not significantly different from each other at $(\mathrm{p}<0.05)$ using Duncan's multiple range test (DMRT)

Interaction of mycorrhiza inoculation with 0 $\mathrm{ml} /$ pot crude oil gave significantly higher $(3.63$, $0.34,0.63,3.82$ and 1.23$) \mathrm{N}, \mathrm{P}, \mathrm{K}, \mathrm{Ca}$, and $\mathrm{Mg}$ uptakes across the weeks evaluated compared to the interaction of $0 \mathrm{ml} /$ pot crude oil and without mycorrhiza inoculation (Table 7). Significantly $\mathrm{mg} / \mathrm{kg}$ ) uptakes were obtained with $0 \mathrm{ml} /$ pot crude oil application compared to other application levels (Table 6). Significantly lower $(2.34,0.13,0.3,2.14$, and $0.70 \mathrm{mg} / \mathrm{kg}$ ) N, P, K, Ca and $\mathrm{Mg}$ uptakes were obtained under $500 \mathrm{mls} /$ pot crude oil application compared to that of $300 \mathrm{mls} /$ pot crude oil application. 
Table 8. Effects of mycorrhizal Inoculation and crude oil on Total Petroleum Hydrocarbon (TPH) content of soil sown with maize at different Weeks After Sowing (WAS)

\begin{tabular}{|c|c|c|c|}
\hline \multirow{2}{*}{ Treatments } & \multicolumn{3}{|c|}{ Total petroleum hydrocarbon $(\mathrm{g} / \mathrm{kg})$} \\
\hline & $\overline{4 W A S}$ & 8WAS & 12WAS \\
\hline \multicolumn{4}{|c|}{ Mycorrhizal Inoculation } \\
\hline $\mathrm{M}^{+}$ & 59.75 & 51.48 & 46.23 \\
\hline $\mathrm{M}^{-}$ & 64.70 & 58.71 & 52.65 \\
\hline LSD (0.05) & 0.38 & 0.42 & 0.43 \\
\hline \multicolumn{4}{|c|}{ Crude Oil (ml/pot) } \\
\hline $\mathrm{C}_{0}$ & BDL & $\mathrm{BDL}$ & BDL \\
\hline $\mathrm{C}_{200}$ & 80.73 & 68.88 & 63.21 \\
\hline $\mathrm{C}_{300}$ & 83.54 & 73.66 & 65.96 \\
\hline $\mathrm{C}_{500}$ & 84.62 & 77.85 & 68.58 \\
\hline LSD (0.05) & 0.54 & 0.59 & 0.60 \\
\hline
\end{tabular}

$\mathrm{M}+=$ with Glomus clarum; $\mathrm{M}-=$ without Glomus clarum; $\mathrm{C} 0=0 \mathrm{ml} ; \mathrm{C} 1=200 \mathrm{mls} ; \mathrm{C} 2=300 \mathrm{mls} ; \mathrm{C} 3=$ $500 \mathrm{mls} ; \mathrm{LSD}=$ Least significant difference, $\mathrm{NS}=$ Not significant, $\mathrm{BDL}=$ Below detection limit.

Mycorrhiza inoculation resulted in weeks (4, 8, and 12 WAS) evaluated compared to significantly lower $(59.75,51.48$, and $46.23 \mathrm{~g} / \mathrm{kg}$ ) other application levels (Table 8 ) while under 500 total petroleum hydrocarbon (TPH) content of the $\mathrm{mls} /$ pot crude oil, TPH content was significantly soil at 4,8 , and 12 WAS compared to non- higher $(84.62,77.85$ and $68.58 \mathrm{~g} / \mathrm{kg})$ compared to mycorrhiza inoculation (Table 8).

The application of $200 \mathrm{mls} /$ pot crude oil resulted in significantly lower $(80.73,68.88$, and $63.21 \mathrm{~g} / \mathrm{kg}$ ) TPH content of the soil throughout the

Table 9. Interaction of Mycorrhizal Inoculation with Crude Oil on total petroleum hydrocarbon (TPH) content of soil sown with maize at different Weeks After Sowing (WAS)

\begin{tabular}{|c|c|c|c|c|}
\hline $\begin{array}{c}\text { Mycorrhizal } \\
\text { inoculation }\end{array}$ & Crude oil (ml/pot) & \multicolumn{4}{|c|}{ Total petroleum hydrocarbon $(\mathrm{g} / \mathrm{kg})$} \\
\hline & & 4WAS & 8WAS & 12 WAS \\
\hline $\mathrm{M}+$ & $\mathrm{C}_{0}$ & BDL & BDL & BDL \\
\hline $\mathrm{M}+$ & $\mathrm{C}_{200}$ & $77.57 \mathrm{e}$ & $64.88 \mathrm{e}$ & $59.11 \mathrm{f}$ \\
\hline $\mathrm{M}+$ & $\mathrm{C}_{300}$ & $80.53 \mathrm{~d}$ & $67.73 \mathrm{~d}$ & $60.86 \mathrm{e}$ \\
\hline $\mathrm{M}+$ & $\mathrm{C}_{500}$ & $80.90 \mathrm{~d}$ & $73.32 \mathrm{c}$ & $64.93 \mathrm{~d}$ \\
\hline $\mathrm{M}-$ & $\mathrm{C}_{0}$ & $\mathrm{BDL}$ & $\mathrm{BDL}$ & BDL \\
\hline $\mathrm{M}-$ & $\mathrm{C}_{200}$ & $83.90 \mathrm{c}$ & $72.89 \mathrm{c}$ & $67.31 \mathrm{c}$ \\
$\mathrm{M}-$ & $\mathrm{C}_{300}$ & $86.56 \mathrm{~b}$ & $79.59 \mathrm{~b}$ & $71.06 \mathrm{~b}$ \\
$\mathrm{M}-$ & $\mathrm{C}_{500}$ & $88.33 \mathrm{a}$ & $82.38 \mathrm{a}$ & $72.23 \mathrm{a}$ \\
\hline
\end{tabular}

Means with the same letter(s) in the same column are not significantly different from each other at $\mathrm{p}<0.05$ using Duncan's multiple range test. BDL: Below detection limit. M+ = with Glomus clarum; $\mathrm{M}-=$ without Glomus clarum.

The interaction of mycorrhiza with 200 $\mathrm{mls} /$ pot crude oil resulted in significantly lower $(77.57,64.88$ and $59.11 \mathrm{~g} / \mathrm{kg})$ TPH content of the contaminated soil at 4,8 , and 12 WAS compared to other treatments (Table 9) while the interaction between $500 \mathrm{mls} /$ pot crude oil and without mycorrhiza inoculation resulted in significantly higher $(88.33,82.38$ and $72.23 \mathrm{~g} / \mathrm{kg}$ ) TPH content of the contaminated soil at 4,8 and 12 WAS compared to that of $300 \mathrm{mls} /$ pot crude oil and without mycorrhiza inoculation.

From the results of this study, it was observed that mycorrhizal inoculation enhances the N, P, K, and $\mathrm{Ca}$ uptakes thus leading to enhanced plant 
height, number of leaves, fresh and dry biomass weights of maize. This could be attributed to the positive effect of mycorrhiza as observed by Zhu et al. (2010), Ortas (2012), Crespo (2015). Mycorrhiza inoculated treatments had significantly higher nutrient uptakes compared to non-inoculated treatments. This result supports the findings of Sun et al. (2018), Smith and Read (2008), and Jung et al. (2012) that mycorrhiza fungi significantly improve plant nutrient uptake. This improvement in nutrient uptake could be attributed to the fungal mediated transport of phosphorus (P) and nitrogen (N) to plants (Smith and Read, 2008), as well as communal nutrients, being relocated from fungi to the plant, together with other related effects (Plassard and Dell, 2010) and the fungal capacity to positively influence the soil characteristics and thus supports plant development in normal as well as stressful conditions (Navarro et al., 2014, Alqarawi et al., 2014a\&b)

The negative impact of petroleum hydrocarbons on plant growth was significantly reduced by mycorrhizal inoculation leading to improved plant growth compared with a noninoculated plant. This implies that mycorrhiza improves the resistance of the plant to several abiotic stress factors as reported by Sun et al. (2018) and Birhane et al. (2012). There was a significant decrease in total petroleum hydrocarbons (TPH) in crude oil contaminated soil due to enhanced degradation of various levels of total petroleum hydrocarbons (TPH) in the contaminated soil as a result of mycorrhizal inoculation. This corroborates the findings of Onwuka et al. (2012) and Nkereuwem et al. (2020b) where they observed an enhanced degradation of total petroleum hydrocarbons (TPH) in crude oil-contaminated soils as a result of mycorrhizal inoculation. The result of this study is supported by the findings of Parish et al. (2005) that reduction in petroleum hydrocarbons toxicity is faster in soils containing plants and mycorrhizal association. It shows that mycorrhizal inoculation not only increases the resilience of plants to polluted soils by crude oil or other pollutants but also leads to changes in the rhizosphere environment thus, increasing the efficiency of degradation or breakdown.

Crude oil contamination impacted the growth indices of maize negatively as evidenced in reduced biomass (fresh and dry weight), plant height, and number of leaves. This is in agreement with the findings of Adenipekun and Kassim (2006) that crude oil pollution is harmful to agricultural soil and this, in turn, impacts the physiological, ecological as well as anatomical development of plants cultivated in these environments. The highest plant height was obtained with the application of $0 \mathrm{ml}$ of crude oil and this was significantly different from the other levels of contamination. This result on plant height corroborates the findings of Osuagwu et al. (2013), Okonokhua et al. (2007), Anoliefo et al. (2010), and Ojimba and Iyagba (2012), where they reported a reduction in plant height of air potato, maize, cowpea and horticultural crops planted in crude oil polluted soils compared to unpolluted soils. The reduced plant growth observed in the crude oil contaminated soil confirms the adverse effect of petroleum hydrocarbons. This reduction may be attributed to the toxic effect of the crude oil and water repellent property of hydrocarbons (Zand et al., 2010). Crude oil contamination had a negative impact on the parameters evaluated and this was more prominent with an increase in crude oil contamination levels. Therefore, the general depression in growth and yield parameters as well as nutrient uptakes observed in this study is due to the detrimental effect of crude oil contamination.

\section{Conclusion}

Results obtained from this study shows that mycorrhiza inoculation significantly improved the tolerance and survival of maize plant to crude oil contamination. Furthermore, growth parameters and nutrient uptake of the same plant were greatly enhanced with mycorrhizal inoculation. Additionally, the effect of crude oil contamination was more pronounced with higher levels of soil contamination. Crude oil reduction from crude oil contaminated soil was noticed in all the soil samples studied nonetheless, the quantity of removal was significantly higher in mycorrhizal inoculated treatments compared to treatments without mycorrhizal inoculation. Hence, owing to the significant TPH removal recorded in this study, the use of AM fungi in addition to planting maize or any other hydrocarbon tolerant plant in hydrocarbons impacted soil is recommended. 


\section{REFERENCES}

Adenipekun, C.O. and Kassim, L.O. (2006). Effects of Spent Engine Oil on the Growth Parameters and Moisture Content of Celosia argentea. Proceedings of the 15th Annual Botanical Society of Nigeria Conference. 48th March, 2006. Akpan, G. and Odoemena, C. S. J. Eds. University of Uyo, Nigeria 108111.

Adipah S. (2019). Introduction of Petroleum Hydrocarbons Contaminants and its Human Effects. Journal of Environmental Science and Public Health 3. 1: 1-9.

Alarcón, A., Davies, F. T. Jr., Autenrieth, R. L. and Zuberer, D.A. (2008). Arbuscular mycorrhiza and petroleum-degrading microorganisms enhance phytoremediation of petroleumcontaminated soil. International Journal of Phytoremediation 10: 251-263.

Alqarawi, A. A., Abd-Allah, E. F., Hashem, A. (2014a). Alleviation of salt-induced adverse impact via mycorrhizal fungi in Ephedra aphylla Forssk. J. Plant. Interact. 9 (1), 802 810.

Alqarawi, A. A., Hashem, A., Abd Allah, E. F., Alshahrani, T. S., Huqail, A. A. (2014b). Effect of salinity on moisture content, pigment system, and lipid composition in Ephedra alataDecne. Acta Biol. Hung. 65 (1), 61-71.

Anoliefo, G. O., Ikhajiagbe, B., Berena, A. T. and Okoro, R. E. (2010). Bioremediation of crude oil-polluted soil by using Vernonia amygdylina and manure. International Research Journal of Biotechnology 1. 4: 3743.

Bharath, Y; Singh, S. N; Keerthiga, G. and Prabhakar, R. (2019). Mycoremediation of

contaminated soil in MSW sites. In: Ghosh SK, editor. Waste Management and Resource Efficiency. Singapore: Springer Nature; pp. 321-329.

Birhane, E., Sterck, F., Fetene, M., Bongers, F., Kuyper, T. (2012). Arbuscular mycorrhizal fungi enhance photosynthesis, water use efficiency, and growth of frankincense seedlings under pulsed water availability conditions. Oecologia 169, 895-904.
Bouyoucos, C. H. (1951). A recalibration of hydrometer method for making mechanical analysis of soils. Agronomy Journal 43. 9: 434-438.

Bray, R. H. and Kurtz, L.T. (1945). Determination of Total Organic and Available Forms of Phosphorus in Soils. Soil Science 59 39-45.

Carling, D. E., Richle, W. G; Brown, M. F. and Johnson, D. R. (1978). Effect of a vesicular arbuscular mycorrhizal fungus on nitrogen reductase and nitrogenase activities in nodulating and non-nodulating soybeans. Phytopatholgy 68: 1590-1596.

Crespo, R. (2015). Impact of Arbuscular Mycorrhizal Fungi on the Physiology of Maize Genotypes under variable nitrogen and phosphorus levels. Theses, Dissertations, and Student Research in Agronomy and Horticulture. 87.

Dadrasnia, A., Salmah, I., Emenike, C.U. and Shahsavari, N. (2015). Remediation of oil contaminated media using organic material supplementation. Petroleum Science and Technology 33: 1030-1037.

de Lima Souza H. M, Sette L. D, da Mota A. J, do Nascimento Neto J. F, Rodrigues A, de Oliveira, T. B. (2016). Filamentous fungi isolate of contaminated sediment in the Amazon region with the potential for benzo(a)pyrene degradation. Water, Air, and Soil Pollution. 227:431.

Frick, C. M., Farrell, R. E. and Germida J. J. (1999). Assessment of phytoremediation as an in-situ technique for cleaning oilcontaminated sites. Report submitted to Petroleum Technology Alliance of Canada. $88 \mathrm{pp}$.

Gong, X. (2012). Remediation of weathered petroleum oil-contaminated soil using a combination of biostimulation and modified fenton oxidation. International Biodeterioration and Biodegradation 70: 8995.

Graj, W., Lisiecki, P., Szulc, A., Chrzanowski, Ł. And Wojtera-Kwiczor, J. (2013). Bioaugmentation with petroleum-degrading consortia has a selective growth-promoting impact on crop plants germinated in diesel 
oil-contaminated soil. Water, Air and Soil Pollution 224: 1-15.

Harms, H; Schlosser, D. and Wick, L.Y. (2011). Untapped potential: Exploiting fungi in bioremediation of hazardous chemicals. Nature Reviews. Microbiology. 9:177-192.

Jackson, M. L. (1958). Soil Chemical Analysis. Prentice Hall Inc. Eaglewood Cliffs, New Jersey 59 - 67.

Jung, S. C., Martinez-Medina, A., Lopez-Raez, J. A., Pozo, M. J. (2012). Mycorrhiza-induced resistance and priming of plant defenses. $J$. Chem. Ecol. 38, 651-664.

Juo, A. S. R.., Ayanlaja, S. A. and Ogunwale. J. A. (1976). An evaluation of cation exchange capacity measurements for soils in the tropics. Communication in Soil Science and Plant Analysis 7. 8: 751-761.

Liu A., Dalpé Y. (2009). Reduction in soil polycyclic aromatic hydrocarbons by arbuscular mycorrhizal leek plants.Int. J. Phytoremediation 11 39-52.

Kapahi, M. and Sachdeva, S. (2017). Mycoremediation potential of Pleurotus species for heavy metals: a review. Bioresour. Bioprocess., 4

Khan, M. Aftab, S. Shakir, M. Ali, S. Qayyum, M.U. Rehman, K.S. Haleem, I. Touseef. (2019). Mycoremediation of heavy metal (Cd and $\mathrm{Cr}$ )-polluted soil through indigenous metallotolerant fungal isolates. Environ. Monit. Assess., 191

McLean, E. (1982). Soil pH and lime requirement. Methods of soil analysis. Part 2. Chemical and microbiological properties. 199 - 224.

Navarro, J. M., Perez-Tornero, O., Morte, A. (2014). Alleviation of salt stress in citrus seedlings inoculated with arbuscular mycorrhizal fungi depends on the root stock salt tolerance. J. Plant Physiol. 171 (1), 7685.

Nelson, D.W. and Sommers, L.E. (1996). Total carbon, organic carbon and organic matter. In: Methods of Soil Analysis, Part 2, 2nd ed., A.L. Page et al., Ed. Agronomy. 9:961-1010. American Society of Agronomy, Inc. Madison, WI.

Nkereuwem, M.E.; Fagbola, O.; Okon, I.E.; Adeleye, A.O.; Nzamouhe, M. (2020a). Bioremediation potential of mycorrhiza fungi in crude oil contaminated soil planted with Costus lucanusianus. Amaz. Jour. of Plant Resear. 4(1): 441-455.

Nkereuwem, M.E., Fagbola, O., Okon, I.E., Edem, I.D, Adeleye, A.O., Onokebhagbe, V.O. (2020b). Influence of a mycorrhizal fungus and mineral fertilizer on the performance of Costus lucanusianus under crude oil contaminated soil. Novel Research in Microbiology Journal 4(3): 808-824.

Ojimba, T. P. and Iyagba, A. G. (2012). Effects of crude oil pollution on Horticultural crops in Rivers State, Nigeria. Global Journal of Science Frontier Research Agriculture and Biology 12. 4: 37-43.

Okonokhua, B. O., Ikhajiagbe, B., Anoliefo, G. O. and Emede, T. O. (2007). The Effects of Spent Engine Oil on Soil Properties and Growth of Maize (Zea mays L.). Journal of Applied Science and Environmental Management 11. 3: 147 - 152.

Olsen, S. R., Cole, C. V., Watanabe, F. S. and Dean. L. A. (1954). Estimation of available phosphorus in soils by extraction with NaHCO3, USDA Circular 939. U.S. Washington.

Onwuka, M. I, Chude, V. O. andOgwuegbu, G. C (2012). Remediation of spent engine oil polluted soil using two types of Organic manure and their effects on maize growth. Nig. J. Soil Sci. 22(2):245.

Ortas, I. (2012). The effect of mycorrhizal fungal inoculation on plant yield, nutrient uptake and inoculation effectiveness under longterm field conditions. Field Crop Resources 125: 35-48.

Osuagwu, A. N, Okigbo, A. U, Ekpo, I. A, Chukwurah, P. N and Agbor, R. B. (2013). Effect of Crude Oil Pollution on Growth Parameters, Chlorophyll Content and Bulbils Yield in Air Potato (DioscoreabulbiferaL.). International Journal of Applied Science and Technology 3. 4: 37-42.

Oyedeji, A.A., Adebiyi, A., Omotoyinbo, M. and Ogunkunle, C. (2012). Effect of crude oilcontaminated soil on germination and growth performance of Abelmoschus esculentus L. Moench- a widely cultivated vegetable crop in Nigeria. American Journal of Plant Sciences 3. 10: 1451-1454. 
Plassard, C., Dell, B. (2010). Phosphorus nutrition of mycorrhizal trees. Tree Physiol. 30, 11291139.

Schnoor, J. L. (1997). Phytoremediation. Ground water technology Analysis Center: Technology. American Chemical Society Madison, WI. 23-26.

Schwab, A. P., Su, J; Wetzel, S; Pekarek, S. and Banks, M. K. (1999). Extraction of petroleum hydrocarbons from soil by mechanical shaking. Environment Science and Technology 33:1940-1945.

Singh, M; Srivastava, P.K; Verma, P.C; Kharwar, R.N; Singh, N. and Tripathi, R.D. (2015). Soil fungi for mycoremediation of arsenic pollution in agriculture soils. J. Appl. Microbiol., 119 pp. 1278-1290.

Soleimani, M.; Afyuni, M.; Hajabbasi, M. A.; Nourbakhsh, F.; Sabzalian, M. R. and Christensen, J. H. (2010). Phytoremediation of an aged petroleum contaminated soil using endophyte infected and non-infected grasses. Chemosphere 81: 1084-1090.

Smith, S. E. and Read, D. J. (2008). Mycorrhizal Symbiosis. 3rd edn. Academic Press.

Sun, Z., Song, J., Xin, X., Xie, X., Zhao, B. (2018). Arbuscular mycorrhizal fungal proteins 14-33- are involved in arbuscule formation and responses to abiotic stresses during AM symbiosis. Front. Microbiol. 5, 9-19.

Teng C-I, Shyu Y-IL, Chiou W-K, Fan H-C, Lam SM. (2010). Interactive effects of nurseexperienced time pressure and burnout on patient safety: a cross-sectional survey. Int $J$ Nurs Stud 47:1442-1450.

Udo, E.J. and Ogunwale, J.A. (1986). Laboratory Manual for Analysis of Soil, Plant and Water Samples. University Press Ibadan 151-162.

Uquetan, U. I, Osang, J. E.1, Egor, A. O.1, Essoka P, A., Alozie, S. I. and Bawan, A. M. (2017). A case study of the effects of oil pollution on soil properties and growth of tree crops in Cross River State, Nigeria. International Research Journal of Pure and Applied Physics 5. 2: 19-28

U.S. EPA. (2017). Test method for evaluating solid wastes, physical and chemical methods. SW 846 method. Online at www.epa.gov $/ \mathrm{hw}-$ 846/846-test-method-3540csoxhletextraction_httml.
Zand, A. D; Bidhendi, G. N. and Mehrdadi, N. (2010). Phytoremediation of total petroleum hydrocarbons (TPHs) using plant species in Iran. Turk Journal of Agriculture 34: 429438.

Zhu, K; Chen, H. and Nan, Z. (2010). Phytoremediation of loess soil contaminated by organic compounds. NATO Science for Peace and Security 159-176. 